\title{
Does Herding Behaviour and Overconfidence Drive the Investor's Decision Making During the Covid-19 Pandemic
}

\author{
Hirdinis M. ${ }^{1}$ \\ ${ }^{1}$ D-3 Management Study Program, Faculty Economics \& Business Universitas Mercu Buana Jakarta and Student of Doctoral \\ Program in Management Science, Faculty Economics \& Business, Barwijaya University, Malang, East Java - Indonesia. \\ ${ }^{1}$ hirdinis@mercubuana.ac.id \\ DOI: 10.47760/cognizance.2021.v01i08.001
}

\begin{abstract}
This study is intended to analyze the effect of herding behavior and overconfidence in encouraging investment decision-making by investors on the Indonesia Stock Exchange in the Jakarta area. The population of this research is investors who invest in investment instruments listed on the Indonesia Stock Exchange in the Jakarta area with an unknown population, and the number of samples in this study is 100 investors. Data analysis in this study used an alternative method of Structural Equation Modeling (SEM) with Wrap PLS 5.0 data processing tools. The findings of this study is herding has a positive and significant effect on investment decisions by investors in the Jakarta area. Overconfidence has a positive and significant effect on investment decisions by investors in the Jakarta area. This means that the increasing herding and overconfidence of investors can drive the investor's decisions making in the Jakarta area.
\end{abstract}

Keywords - Herding Behavior, Overconfidence, Investment Decision, Investor Area Jakarta, Structural Equation Modeling (SEM), Warp PLS.

\section{INTRODUCTION}

The Indonesian government announced two positive cases of Covid-19 patients, for the first time on March 2, 2020. The coronavirus that causes Covid-19 had entered Indonesia since early January, Pranita E. \& Nursastri (2020). The Covid-19 pandemic has caused negative growth in the Indonesian economy and has an impact on the Indonesia Stock Exchange. The composite stock price index (JCI) touched its lowest level this year at 3,937.63 position on March 24, 2020, Azis (2020). Negative economic growth is caused by declining household consumption and gross fixed capital formation, Suryanto \& Handoyo (2020). The decline in gross fixed capital formation nationwide was due to the fact that many companies experienced decreased income and reduced investment in these companies.

If a country's national income increases, the country's economic growth will increase, so that it will encourage investors to invest, Fauziana (2014). According to Muchayatin \& Dita (2018), community investment decision-making is influenced by management/investor policies in using funds held in an asset, which are expected to provide benefits in the future. The right investment decisions will provide the benefits expected by investors. Based on the publication of the Investment Coordinating Board (BKPM) 2020, investment realization data for the January-September 2020 period, with a total investment of IDR 611.6 trillion, an increase of about $1.7 \%$ compared to the same period in 2019, which was IDR 601.3 trillion. The investment value for the January-September 2020 period for Domestic Investment (PMDN) was IDR 309.9 trillion, an increase of around 9.3\% compared to the same period in 2019 of IDR 283.5 trillion and foreign investment (PMA) of IDR. 301.7 Trillion, decreased by around 5.1\% compared to the same period in 2019 amounting to Rp. 317.8 Trillion (BKPM, 2020). The increase in the value of Domestic Investment (PMDN) and the decrease in the value of foreign investment in FDI shows that domestic investors are increasingly knowledgeable and capable of investing.

Investors consist of the owners of shares, debt securities, mutual funds, government securities (SBN), and other securities registered in KSEI. The growth in the number of investors on the Indonesia Stock Exchange can be seen from the total Single Investor Identification (SID). The number of Mutual Fund Investors increased by 49.39\% from 1,774,493 at the end of 2019 to 
2,650,877 investors as of October 16, 2020. The number of Capital Market Investors increased by $34.78 \%$ from 2,484,354 at the end of 2019 to 3,348,396 investors as of October 16, 2020, (Press Release Indonesian Central Securities Depository (KSEI).

In Fig. 1, the asset value recorded in the C-BEST system up to 16 October 2020 has decreased by $14.82 \%$ from Rp4,465.41 trillion to Rp3,803.45 trillion. This is in line with the decline in the JCI by $18.3 \%$. Asset value recorded in another main KSEI system, namely S-INVEST, decreased by $6.15 \%$ from Rp789.80 trillion to Rp756.47 trillion. Meanwhile, the number of Mutual Funds decreased from 2,506 to 2,418.

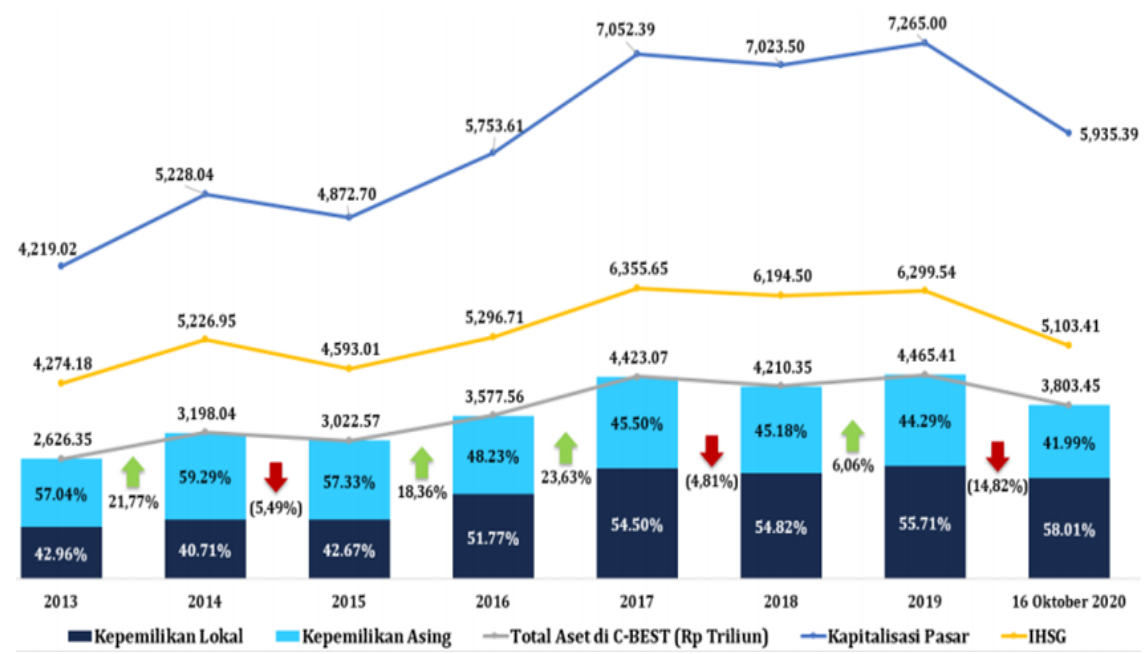

Fig. 2. Recorded Asset Growth at C-BEST

Source : Press Release KSEI, 2020

Investment decision-making by an investor must be based on good knowledge, however, most investors do not have sufficient knowledge of investment and economic concepts. So they make investment decisions based solely on emotions, feelings, fantasies and sentiments, Statman et.al. (2008) and Anthony \& Joseph (2017). Qasim et al. (2018) conducted research on the relationship between investors in decision-making with herding and bias overconfidence.

Nengzih (2017) states that institutional investors make investment analysis by assessing the information collected to control the process effectively. Trenca et al. (2015) stated that institutional investors tend to imitate the behavior of other investors, while this statement does not apply to individual investors. Investor herding behavior according to Filip et.al, (2015) is the main cause of speculative bubbles and implies that investors take similar trading decisions that can cause stock prices to deviate from their fundamental values.Short-selling restrictions according to Tiniç (2020) can strengthen herding behavior because an informed investor cannot eliminate the possibility of price alignment. Qin (2012) identified that investors observe the buying and selling decisions of other investors and then investing. In the case of the rational herding model, investors follow other investors' actions, because their actions reveal personal information to other investors. The results of the research by Qasim et al. (2018), Vo \& Phan (2016), and Metawa et al. (2019), found that herding significantly influences investment decisions. Different research results by Bakar and Amelia (2019) found herding behavior did not have a significant effect on investor decision-making.

According to Adi (2015), rapid decision-making under conditions of risk and uncertainty makes day trader investor behavior influenced by cognitive bias and psychological bias, coupled with emotions induced by the external environment, causing overconfidence behavior. Research by Bouteska and Regaieg (2017), found that analysts in the Tunisian stock market on average were overconfident with their forecasts, and there was clearly an overall overreaction to changes in past earnings. The results of the research by Qasim et al. (2018), Shah, Ahmad, and Mahmood (2018), Metawa et al. (2019), and Grežo, M. (2021), found that overconfidence significantly affects investment decisions by investors. Herlina et.al. (2020) in the study found that overconfidence has a positive effect on investment decisions. Findings of the study (Rahim et.al, 2020) suggest that overconfidence has a positive impact on individual investor decisions in PSX post COVID-19. Meanwhile, research by Gozalie and Anastasia (2015) found that overconfidence has no effect on investment decisions.

The inconsistent results of previous studies were the driving factor for this study. From the research gap, this study seeks to analyze how the influence of herding behavior and overconfidence drives investment decisions by investors in the Jakarta area. In this study, apart from irrational investors, rational investors can make investment decisions that are influenced by herding behavior and overconfidence. The difference between this study and previous research, the respondent, is that the 


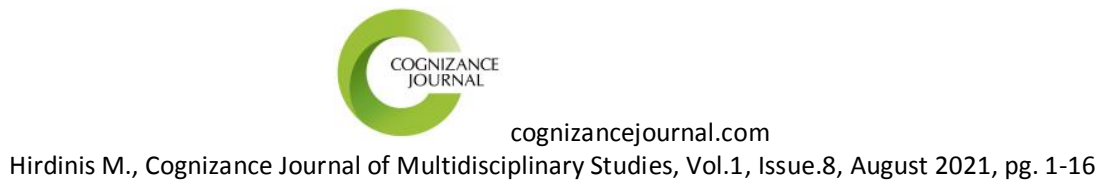

ISSN: 0976-7797

research was carried out during the Covid-19 pandemic and with investors investing in all investment instruments on the Indonesia Stock Exchange in the Jakarta area using herding and overconfidence as independent variables. The theoretical contribution of this research is expected to be able to contribute thoughts and references for further researchers regarding investment decision-making. The practical contribution of this research is to be considered for investors who make the right investment decisions and provide additional information and data for related parties in making investment decisions.

\section{LITERATURE REVIEW}

\section{A. Investment Decisions}

Investment is a commitment to current resources in the hope of obtaining greater resources in the future, Bodie, Ken, and Marcus (2018). In essence, investment is an activity to place a number of funds that you own in the hope of obtaining profits in the future (Zulfikar 2016). Meanwhile, according to Azis, Mintarti, and Nadir (2015) investment are a number of funds or other resources that are carried out at this time with the aim of obtaining a number of benefits in the future. Investment can be interpreted as a commitment to activities in placing a number of funds currently owned with the aim of obtaining future benefits.

Tandelilin, (2017) explain, that people should make decisions such as how much current income should be consumed and invested according to their preferences. According to (Pratiwi and Prijati, 2015) the most basic things in investment decisions are related to returns and risks. According to (Puspitaningtyas 2012), states that an investment decision is a decision to buy, sell, or maintain share ownership. Investment decision-making does not always consistently behave according to the assumptions of the perception, and understanding of the information received Christanti and Mahastanti (2011); Peteros and Maleyeff (2013).

Pasewark and Riley (2010) Divided investment decisions into four components (namely, risk, payment, company data, and community criteria) and consisted of a total of 14 questions. According to (Tandelilin 2017) the investment decision process is a continuous decision process, consisting of five stages of decisions that run continuously until the best investment decision is reached. First, the determination of investment objectives, second; determination of investment policy, third; portfolio strategy selection; fourth; asset selection to be included in the portfolio and fifth; portfolio performance measurement and evaluation. The variable indicator of investment decision-making according to Wulandari and Iramani, 2014) is the use of income for risky investment, investment without consideration, investment without collateral, investment based on intuition/feeling

According to (Sukirno 2014) there are several factors that influence an individual or institution to invest, including: interest rates, national income per capita and Gross Regional Domestic Product (GRDP) per capita, conditions of facilities and infrastructure, licensing bureaucracy, quality of human resources, labor regulations and laws, political stability and security, exchange rates, and inflation rates.

\section{B. Herding Behavior}

According to Komalasari 2016, herding behavior occurs when the knowledge of another investor's investment decisions changes an investor's investment decision from not investing to investing or vice versa. According to Qasim et.al. (2019), herding behavior is investing safely without making their own strategies where investors imitate the work of others. The results of Chaffai and Medhioub's 2018 research, found evidence of herding behavior during an up market only in the GCC market. According to (Kramer and Nautz 2013.) Herding behavior occurs when the market is not transparent, that is, when investors face uncertainty about sources of public information and receive unclear signals about companies in the future.

Research results Rahayu et.al. (2021.) Show that the social influence originating from expert investors was more influential than the Book Value per Share (BVPS) information on the behavior of herding investors in making investment decisions. Galariotis et.al. (2015.) Describe herding spillover as a condition when herding behavior occurs in a market caused by the spread of events from other markets. Chang et.al. (2013), estimate that herding behavior across the Pacific equity markets is positively correlated, meaning that there are similarities in herding behavior in the region. (Chen and Pelger 2013.) Identified the impact of compensation on herding behavior through the black-holes model, where herding is driven by risk aversion and relative compensation. Trenca et.al. (2015), and Metawa et.al. (2019.) Say that herding has a significant effect on investment decisions for individual investors. Based on the theory and results of previous research, the following hypotheses can be made: H1: Herding has a positive effect on investment decisions. 


\section{Overconfidence}

The concept of overconfidence has been derived from a large number of psychological experiments and surveys in which subjects overestimate both their own predictive abilities as well as the precision of the information they have been given (Pompian, 2012). According to Pompian (2017), overconfidence is a situation where investors have unreasonable beliefs in their own judgment, reasoning, and analytical abilities. Grežo, M. (2021), in his research stated that overconfidence is mostly related to investment, followed by trade and innovation According to Supramono and Wandita (2017) overconfidence bias often occurs in novice investors who want to be fast and get high returns with their own confidence. Overconfidence behavior can lead to higher trading volumes (Mushinada \& Veluri, 2018 and Phan, Rieger, \& Wang, 2018). Research by Qasim et al. (2018) and Metawa et al. (2019), found that overconfidence significantly affects investment decisions by investors. Based on previous theory and research, the following hypotheses can be made:

H2: Overconfidence bias has a positive effect on investment decisions.

\section{RESEARCH METHODS}

\section{A. Research design}

The research design used in this research is causal research. Causal is a relationship that is causal, so there are variables that influence and variables that are affected (Sugiyono, 2016). This study is to determine the effect of one or more independent variables on the dependent variable by requiring hypothesis testing with statistical tests. In this study, the independent variables are herding behavior and overconfidence, the independent variable is the investment decision.

\section{B. Definition and Operationalization of Variables.}

1) Variable Definition: This study uses 2 (two) kinds of variables to be examined, namely the independent variable and the dependent variable. The independent (exogenous) variables of this study were herding behavior (X1), overconfidence (X2), herding behavior, according to Qasim et.al. (2019), is investing safely without making their own strategies, where investors imitate the work of others. Overconfidence, according to Pompian (2017), is a situation where investors have unreasonable beliefs in their own judgment, reasoning, and analytical abilities. The dependent variable (endogenous) in this study is the investment decision (Y). An investment decision according to Puspitaningtyas (2012) is a decision to buy, sell, or maintain share ownership.

2) Variable Operationalization: This research uses a semantic differential interval scale. The semantic differential scale according to Rosenberg \& Navarro (2018) is a survey or questionnaire rating scale that asks people to rate a product, company, brand or any entity in a multi-point ranking option frame. The semantic differential scale most often contains between 8 and 12 adjective pairs. As a general rule, the researcher must balance completeness (that is, measuring each component of the attitude object) and practicality (that is, asking the respondent to provide answers to a number of questions that make sense). Each question is scored using a scoring system in order to determine the weight of the assessment. The operationalization of this research variable can be seen in table 1 as follows:

TABLE I

VARIABLE OPERATIONS

\begin{tabular}{|c|c|c|c|}
\hline Variable & Dimentions & Indicator & Scale \\
\hline $\begin{array}{l}\text { Herding (X1) } \\
\text { Kumar \& Goyal (2015) } \\
\text { Fityani (2015) }\end{array}$ & $\begin{array}{l}\text { a. Copying other people's decisions. } \\
\text { b. Look at the current market. }\end{array}$ & $\begin{array}{l}\text { 1) Investment decisions depend on other } \\
\text { people's investment decisions. } \\
\text { 2) Quickly react to changes in other investors' } \\
\text { decisions. } \\
\text { 3). It is preferable to invest if the investment } \\
\text { has been in demand since the beginning of } \\
\text { trading. }\end{array}$ & Interval \\
\hline $\begin{array}{l}\text { Overconfidence (X2) } \\
\text { Subash (2012), } \\
\text { Setiawan et al. (2018) }\end{array}$ & $\begin{array}{l}\text { a. High confidence } \\
\text { b. Predicting the future } \\
\text { c. Have higher investment knowledge }\end{array}$ & $\begin{array}{l}\text { 1) Believe in your own abilities. } \\
\text { 2) Memiliki keyakinan terhadap keberhasilan } \\
\text { suatu rencana } \\
\text { 3) Be able to predict the right investment. } \\
\text { 4) Has an investment performance above the } \\
\text { average of other investors. }\end{array}$ & Interval \\
\hline
\end{tabular}




\begin{tabular}{|c|c|c|c|}
\hline Investment Decision (Y) & a. Use of income for risky investment & 1) Making a profit. & Interval \\
\hline Wulandari \& Iramani, & b. Investments without collateral & 2) Knowing how to manage finances & \\
\hline $\begin{array}{l}\text { (2014) Subash (2012), } \\
\text { Setiawan et al. (2018) }\end{array}$ & $\begin{array}{l}\text { c. Selection of various investment } \\
\text { alternatives }\end{array}$ & 3) Investment decisions for the future & \\
\hline
\end{tabular}

\section{Population and Research Sample}

According to Sugiyono (2016) the population in the study is a generalization area consisting of objects / subjects that have certain quantities and characteristics that the researcher determines to study and then draw conclusions. The population of this study is an unknown number of investors in the Jakarta area because no data can be found from reliable sources. According to Sugiyono (2016) the sample is part of the number and characteristics of the population. Sampling in this study was carried out with a representative method according to Hair et al. (2016) depends on the number of indicators multiplied by 5 to 10 . The number of samples in this study are:

Sample $=$ number of indicators $\times 10=10$ indicators $\times 10=100$

Based on the calculation, the minimum sample size used in this study is 100 respondents. So the number of samples used in this study were 100 respondents.

\section{Data Collection Techniques}

According to Sugiyono (2016) a questionnaire is a data collection technique that is carried out by giving a set of questions or written statements to respondents to be answered. The questionnaire was distributed using google form to the sample via email and social media. The theory used to support the research is obtained from literature study. The data sources of this research are: 1). Primary data were collected through a list of questions to the respondents of this study. 2). Secondary data comes from books, journals and the internet related to research titles.

\section{E. Data analysis method}

1) Descriptive Analysis: Descriptive statistics are used to provide an overview of the sample data profile consisting of the minimum, maximum, mean and standard deviation. In this study, researchers used the Partial Least Square (PLS) method. PLS is a method of solving structural equation modeling (SEM) that is more precise than other SEM techniques. Data processing using Microsoft Excel 2010 and WarpPLS 5.0 software.

2) Evaluation of the Measurement Model: The evaluation of the model in PLS includes 2 stages, namely the evaluation of the Outer Model or measurement model and evaluation of the inner model or structural model.

a. Outer model: The outer model specifies the relationship between latent constructs and its indicators. The equation for the outer model is:

$$
\begin{aligned}
& \mathbf{X}=\pi_{\mathrm{x}} \xi+\varepsilon_{\mathbf{x}} \\
& \mathbf{Y}=\pi_{\mathrm{y}} \boldsymbol{\eta}+\varepsilon_{\mathbf{y}}
\end{aligned}
$$

Where:

$\mathrm{X}=$ The manifest variable matrix is associated with the exogenous latent constructs $\xi$

$\mathrm{Y}=$ The manifest variable matrix relates to the latent endogenous constructs $\eta$

$\pi_{\mathrm{x}}$ and $\pi_{\mathrm{y}}=$ Coefficient matrix (loading matrix)

$\varepsilon_{\mathrm{x}}$ and $\varepsilon_{\mathrm{y}}=$ The residual outer model matrix

Convergent Validity, measures the magnitude of the correlation between constructs and latent variables. Measurement (indicators) with the construct, the loading factor value above 0.7 can be said to be ideal, meaning that the indicator is valid as a construct measurement indicator. However, the standard loading factor values above 0.5 are acceptable, while those below 0.5 are excluded from the model.

Discriminant Validity, from the reflective model evaluated through cross loading, then comparing the AVE value with the square of the correlation value between constructs (or comparing the AVE root with the correlation between constructs). Cross loading measure is to compare the correlation of the indicator with its constructs and constructs from other blocks. If the indicator with a construct is higher than its correlation in other blocks, it means the construct predicts the size better than the other blocks. 
Composite Reliability is done by looking at the coefficient value of the latent variable. From this output, the criteria are seen from two things, namely composite reliability and Cronbach's alpha. Both must be valued above 0.70 as a condition for reliability. Chin stated that cronbach's alpha in PLS is said to be good if it is $\geq 0.5$, and it is said to be sufficient if it is $\geq 0.364$. If a construct meets these two criteria, the construct is reliable or has consistency in the research instrument of Ghozali, (2016).

b. Inner Model: The Inner Model specifies the relationship between latent constructs and other latent constructs. The equation of the inner model is as follows:

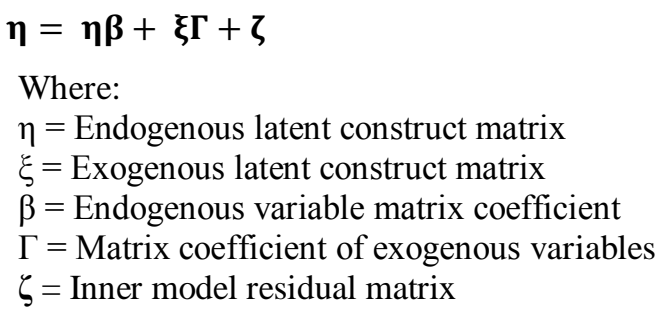

Evaluation of the structural model (inner model) includes the fit model test, path coefficient, and $\mathrm{R}^{2}$. Model fit test is used to determine whether a model has a fit with the data. In the fit model test, there are 3 test indices, namely the average path coefficient (APC), average r-squared (ARS) and average variance factor (AVIF). The p-value for APC and ARS must be less than 0.05 or significant. In addition, AFIV as an indicator of multicollinearity must be less than 5 . The following table 2 shows the Summary of Rule of Thumb for Evaluation of Structural Models:

TABLE 2

SUMMARY OF RULE OF THUMB FOR STRUCTURAL MODEL EVALUATION

\begin{tabular}{ll}
\hline \multicolumn{1}{c}{ Index } & Criteria \\
\hline APC & P-value $\leq 0.05$ \\
ARS & P-value $\leq 0.05$ \\
AARS & P-value $\leq 0.05$ \\
AVIF & $\leq 5$, ideal $\leq 3.3$ \\
AFVIF & $\leq 5$, ideal $\leq 3.3$ \\
GoF & $\geq 0.1$ kecil, $\geq 0.25$ menengah, $\geq 0.36$ besar \\
SPR & $\geq 0.7$, ideal 1 \\
RSCR & $\geq 0.7$, ideal 1 \\
SSR & $\geq 0.7$ \\
NLBCDR & $\geq 0.7$ \\
\hline
\end{tabular}

Source: Ghozali (2016)

\section{F. Hypothesis test}

Hypothesis testing is used to explain the direction of the relationship between the independent variable and the dependent variable. A hypothesis is accepted or rejected statistically can be known through its significance level. Usually the significance levels used in a study are $10 \%, 5 \%$, and $1 \%$. In this study, the significance level was $5 \%$. If the significance level is greater than $5 \%$, the hypothesis is rejected and if it is smaller than 0.05 , the hypothesis is accepted. This means that there is a $5 \%$ chance of making the wrong decision. As a basis for decision-making in this study, namely: $\mathrm{p}$-value $\geq 0.05$, then Ho is accepted and $\mathrm{p}$ value $<0.05$, then Ho is rejected and Ha is accepted.

\section{RESULTS AND DISCUSSION}

\section{A. Characteristics of Respondents:}

In the results of questionnaires that have been distributed to respondents, it can be seen that the characteristics of the respondents are based on gender, age, education and income. Based on Table 3, it can be seen that the respondents were dominated by women by $56.4 \%$ or 54 people. And are at the age of $26-30$ years of 36 people or $36.4 \%$. With a level of education as many as 48 people or $48.2 \%$ dominant with a bachelor's level. The dominant income is $50.9 \%$ or 51 people have 
an income of IDR 5,000,000 to IDR 10,000,000. A more detailed explanation of the characteristics of the respondent can be seen in table 3, below:

TABLE 3.

CHARACTERISTICS OF RESPONDENTS BASED ON GENDER, AGE, EDUCATION, AND INCOME

\begin{tabular}{lcc}
\hline Information & Number of People & Percentage (\%) \\
\hline Gender & & \\
Male & 44 & 43.6 \\
Female & 56 & 56.4 \\
Age & 22 & 21.8 \\
21 - 25 years & 36 & 36.4 \\
26 - 30 years & 28 & 28.2 \\
31 - 35 years & 11 & 10.9 \\
36 - 40 years & 3 & 2.7 \\
> 40 years & & \\
Education & 13 & 12.7 \\
High school & 36 & 36.4 \\
Diploma & 48 & 48.2 \\
Bachelor & 3 & 2.7 \\
Master/ Doktor & & \\
Income & 51 & 50.9 \\
Rp 5.000.000 s/d Rp 10.000.000 & 21 & 20.9 \\
Rp 11.000.000 s/d Rp 15.000.000 & 12 & 12.0 \\
Rp 16.000.000 s/d Rp 20.000.000 & 14 & 14.4 \\
Rp 21.000.000 s/d Rp 25.000.000 & 2 & 1.8 \\
$>$ Rp 25.000.000 & & \\
\hline Source: Processed Data & $2021)$ & \\
\hline
\end{tabular}

Source : Processed Data (2021)

\section{B. Descriptive Statistics of Respondents' Answer Characteristics}

Descriptive statistical test results are used to analyze data by describing or describing the data that has been collected as it is, without intending to make generalized conclusions or generalizations. The data used in this study are respondents' responses regarding herding, overconfidence, and investment decisions by respondents. Based on the distribution of questionnaires, the results can be described as follows:

1) Results Description of the Herding Questionnaire Answers: Based on the distribution of questionnaires to respondents, the following results were obtained: Based on Table 4, the results of the herding variable with the highest mean value of 4.05 are obtained on the indicator: "Make an investment if it is in demand from the start of the trade." With the statement: "Prefer to make investment decisions if there are many investor enthusiasms from the start." An investor is easier to make investment decisions for without having to learn investing first. The lowest mean value is 3.34 on the indicator "Investment decisions depend on other people's investment decisions" with the statement "Investing in imitation of other people's decisions". This can be due to the many wrong investment decisions that can result in fraudulent investment.

TABLE 4.

THE DISTRIBUTION OF QUESTIONNAIRES TO RESPONDENTS HERDING VARIABLE

\begin{tabular}{|c|c|c|c|c|c|c|c|c|}
\hline Indicator & & Statement & 5 & 4 & 3 & 2 & 1 & Mean \\
\hline \multirow{2}{*}{$\begin{array}{l}\text { 1. Investment } \\
\text { decisions depend on } \\
\text { other people's } \\
\text { investment decisions. }\end{array}$} & 1) & Invest in imitating the decisions of others & 30 & 21 & 18 & 15 & 16 & 3.34 \\
\hline & 2) & $\begin{array}{l}\text { Investment decisions based on rumors } \\
\text { circulating in the market. }\end{array}$ & 20 & 28 & 35 & 16 & 1 & 3.50 \\
\hline \multirow{2}{*}{$\begin{array}{l}\text { 2. Quickly react to } \\
\text { changes in other } \\
\text { investors' decisions. }\end{array}$} & 3) & $\begin{array}{l}\text { React quickly to the behavior of other } \\
\text { investors. }\end{array}$ & 17 & 37 & 34 & 11 & 1 & 3.58 \\
\hline & $\overline{4)}$ & $\begin{array}{l}\text { Make investment decisions based on market } \\
\text { flows. }\end{array}$ & 19 & 29 & 32 & 18 & 2 & 3.74 \\
\hline
\end{tabular}


3. Make an investment if it is in demand from the start of the trade.

\begin{tabular}{|c|c|c|c|c|c|c|c|}
\hline 5) & $\begin{array}{l}\text { Investment decisions are made based on a } \\
\text { majority of votes. }\end{array}$ & 23 & 31 & 29 & 16 & 1 & 3.59 \\
\hline 6) & $\begin{array}{l}\text { Prefer to make investment decisions if } \\
\text { there are many investor enthusiasms from } \\
\text { the start. }\end{array}$ & 33 & 50 & 8 & 7 & 2 & 4.05 \\
\hline
\end{tabular}

Source: Processed Data (2021)

2). Results Description of the Overconfidence Questionnaire Answers: Based on Table 5, the results of the study of the Overconfidence variable with the highest mean indicator of 4.38, namely: "Believe in your own abilities ", with the statement: Believe in the decisions taken. So, the average respondent already knows about investing and is used to investing. At the lowest mean value of 3.80 for the indicator: Having skills above other investors, with the statement: "Having investment knowledge above other investors". Because the respondent has made an investment decision but is not ready for the worst risk of the investment made. The descriptive data on the distribution of questionnaires to respondents can detail in Table 5, as follows:

TABLE 5.

VARIABLE OVERCONFIDENCE BIAS

\begin{tabular}{|c|c|c|c|c|c|c|c|c|}
\hline Indicator & & Statement & 5 & 4 & 3 & 2 & 1 & Mean \\
\hline \multirow{2}{*}{$\begin{array}{l}\text { Believe in your } \\
\text { own abilities }\end{array}$} & 1) & Believe in the knowledge they have & 34 & 42 & 6 & 16 & 2 & 4.32 \\
\hline & 2) & Believe in the decisions taken & 32 & 46 & 8 & 10 & 4 & 4.38 \\
\hline \multirow[t]{2}{*}{2.} & 3) & $\begin{array}{l}\text { Able to predict investment decisions } \\
\text { appropriately }\end{array}$ & 27 & 57 & 11 & 4 & 1 & 4.05 \\
\hline & 4) & Able to predict future profitable investments & 28 & 55 & 5 & 11 & 1 & 3.98 \\
\hline \multirow[t]{2}{*}{ 3. $\mathrm{Ha}$} & 5) & Investment performance is above average & 37 & 50 & 6 & 5 & 2 & 4.15 \\
\hline & 6) & Having investment knowledge above other & 26 & 45 & 17 & 7 & 5 & 3.80 \\
\hline
\end{tabular}

Source::Processed Data (2021)

Results of the Descriptions of Answers to the Investment Decision Questionnaire. In Table 6, the results show that the highest mean value for the location variable with the indicator of make a profit in the statement "Investment decisions are chosen as long as profit without thinking" is 4.11 . Because the respondents hope that investing can make the future secure. For the lowest mean value of 3.44 on the indicator of making a profit with the statement "Investment decisions are chosen from profit without thinking carefully" this is because respondents are more selective in making investment decisions. Based on the distribution of questionnaires to respondents, the following results were obtained:

TABLE 6.

\section{VARIABLES OF INVESTMENT DECISIONS}

\begin{tabular}{|c|c|c|c|c|c|c|c|}
\hline Indicator & Statement & 5 & 4 & 3 & 2 & 1 & Mean \\
\hline \multirow[b]{2}{*}{ 1. Making a profit } & 13) Get a profit from the funds invested & 45 & 36 & 6 & 11 & 2 & 4.11 \\
\hline & $\begin{array}{l}\text { 14) Investment decisions are chosen as long as } \\
\text { profit without thinking carefully }\end{array}$ & 29 & 23 & 19 & 21 & 8 & 3.44 \\
\hline $\begin{array}{l}\text { 2. Know how to } \\
\text { manage finances }\end{array}$ & $\begin{array}{l}\text { 15) Investment decisions based on knowledge of } \\
\text { financial budgeting }\end{array}$ & 30 & 54 & 10 & 4 & 2 & 4.06 \\
\hline $\begin{array}{l}\text { 3. Investation } \\
\text { decisions for the } \\
\text { future }\end{array}$ & $\begin{array}{l}\text { 18) Investment decisions become an alternative } \\
\text { for the future because of the benefits offered }\end{array}$ & 31 & 50 & 9 & 8 & 2 & 4.00 \\
\hline $\begin{array}{l}\text { 4. Investments without } \\
\text { consideration }\end{array}$ & 19) Investment decisions are made without & 30 & 44 & 17 & 5 & 4 & 3.91 \\
\hline
\end{tabular}

Source: Processed Data (2021) 


\section{Data Analysis}

1) Component Based Structural Equation Modeling: is an alternative to covariance based SEM, which can be used to analyze data is WarpPLS. Variance-based SEM assumptions are a guide for SEM-based variance modeling both in the data collection and processing processes using WarpPLS 5.0.

2) Evaluation of the Measurement Model (Outer Model): Analysis of the outer model to ensure valid and reliable measurements for each indicator. The Outer Model is a measurement model that consists of indicators and interconnected paths. Based on table 7 it can be seen that the loading factor value is $>0.7$ and the P-value $<0.001$ for the test results of confirmatory factor analysis, so that the herding variable (X1), overconfidence (X2), and investment decision (Y) are all valid results. The results of the correlation output between the indicators and their constructs can be seen in table 7.as follows:

TABLE 7

TEST OF CONFIRMATORY FACTOR ANALYSIS (OUTER LOADING)

\begin{tabular}{cccc}
\hline Variable & Indicator & Outer Loading & Keterangan \\
\hline \multirow{3}{*}{ Herding $\left(\mathbf{X}_{1}\right)$} & HE1 & 0.84 & VALID \\
& HE2 & 0.89 & VALID \\
& HE3 & 0.88 & VALID \\
& HE4 & 0.88 & VALID \\
& HE5 & 0.84 & VALID \\
& HE6 & 0.74 & VALID \\
\hline \multirow{3}{*}{ Overconfidence Bias $\left(\mathbf{X}_{2}\right)$} & OC1 & 0.73 & VALID \\
& OC2 & 0.79 & VALID \\
& OC3 & 0.79 & VALID \\
& OC4 & 0.81 & VALID \\
& OC5 & 0.76 & VALID \\
& OC6 & 0.77 & VALID \\
\hline Investment Decisions (Y) & ID1 & 0.79 & VALID \\
& ID2 & 0.82 & VALID \\
& ID3 & 0.71 & VALID \\
& ID4 & 0.86 & VALID \\
& ID5 & 0.78 & VALID \\
& ID6 & 0.81 & VALID \\
& ID7 & 0.84 & VALID \\
& ID8 & 0.76 & VALID \\
\hline Source: Processed Data (2021) & & &
\end{tabular}

Furthermore, based on table 8 the output value of the the three constructs have met the convergent validity, which is part of the outer model, which has a loading factor of $>0.70$ and a p-value of 0.05 , has AVE $>0.50$ has met composite reliability $>$ 0.70, with this, the outer model can be accepted. Composite Reliability and Cronbach's Alpha. Testing composite reliability and Cronbach's Alpha to test the reliability of the research model instrument or measure the internal consistency. The results of the evaluation of the outer model are as shown in table 8, below:

TABLE 8.

OUTER MODEL EVALUATION OUTPUT

\begin{tabular}{|c|c|c|c|c|c|c|c|c|c|c|}
\hline \multirow[t]{2}{*}{ No. } & \multirow[t]{2}{*}{ Variable } & \multirow{2}{*}{ Indicator } & \multirow{2}{*}{$\begin{array}{l}\text { Factor } \\
\text { Loading }\end{array}$} & \multirow{2}{*}{ p-value } & \multicolumn{2}{|c|}{ Indicator } & \multirow[t]{2}{*}{ AVE } & \multirow[t]{2}{*}{ CR } & \multicolumn{2}{|c|}{ Variable } \\
\hline & & & & & Validity & Reliability & & & Validity & Reliability \\
\hline \multirow[t]{6}{*}{1} & Herding & HE1 & 0.84 & $>0.001$ & Valid & Reliable & 0.781 & 0.939 & Valid & Reliable \\
\hline & & HE2 & 0.89 & $>0.001$ & Valid & Reliable & & & Valid & Reliable \\
\hline & & HE3 & 0.88 & $>0.001$ & Valid & Reliable & & & Valid & Reliable \\
\hline & & HE4 & 0.88 & $>0.001$ & Valid & Reliable & & & Valid & Reliable \\
\hline & & HE5 & 0.84 & $>0.001$ & Valid & Reliable & & & Valid & Reliable \\
\hline & & HE6 & 0.74 & $>0.001$ & Valid & Reliable & & & Valid & Reliable \\
\hline
\end{tabular}


cognizancejournal.com

Hirdinis M., Cognizance Journal of Multidisciplinary Studies, Vol.1, Issue.8, August 2021, pg. 1-16

ISSN: 0976-7797

\begin{tabular}{|c|c|c|c|c|c|c|c|c|c|c|}
\hline \multirow[t]{6}{*}{2} & \multirow{6}{*}{$\begin{array}{c}\text { Over- } \\
\text { confidence }\end{array}$} & OC1 & 0.73 & $>0.001$ & Valid & Reliable & \multirow[t]{6}{*}{0.685} & \multirow[t]{6}{*}{0.932} & Valid & Reliable \\
\hline & & $\mathrm{OC} 2$ & 0.79 & $>0.001$ & Valid & Reliable & & & Valid & Reliable \\
\hline & & OC3 & 0.79 & $>0.001$ & Valid & Reliable & & & Valid & Reliable \\
\hline & & OC4 & 0.81 & $>0.001$ & Valid & Reliable & & & Valid & Reliable \\
\hline & & OC5 & 0.76 & $>0.001$ & Valid & Reliable & & & Valid & Reliable \\
\hline & & OC6 & 0.77 & $>0.001$ & Valid & Reliable & & & Valid & Reliable \\
\hline \multirow[t]{6}{*}{3} & Investment & ID1 & 0.79 & $>0.001$ & Valid & Reliable & \multirow[t]{6}{*}{0.766} & \multirow[t]{6}{*}{0.973} & Valid & Reliable \\
\hline & \multirow[t]{5}{*}{ Decisions } & ID2 & 0.82 & $>0.001$ & Valid & Reliable & & & Valid & Reliable \\
\hline & & ID3 & 0.71 & $>0.001$ & Valid & Reliable & & & Valid & Reliable \\
\hline & & ID4 & 0.86 & $>0.001$ & Valid & Reliable & & & Valid & Reliable \\
\hline & & ID5 & 0.78 & $>0.001$ & Valid & Reliable & & & Valid & Reliable \\
\hline & & ID6 & 0.81 & $>0.001$ & Valid & Reliable & & & Valid & Reliable \\
\hline
\end{tabular}

Source: WarpPLS 5.0 outputs, Processed Data (2021).

Table 9, shows the results of the composite reliability test where all variables are reliable, all latent variables have a composite reliability value greater than or equal to 0.70 . It means that the statement instruments are able to measure each variable. It can be said that the respondent's perception or response will remain the same even though the test is carried out more than once. The results of the Composite Reliability test can be seen in table 9 below:

TABLE 9

COMPOSITE RELIABILITY TEST

\begin{tabular}{lcl}
\hline Variable & Composite Reliability & Results \\
\hline Herding & 0.939 & Reliable \\
Overconfidence & 0.932 & Reliable \\
Investment Decisions & 0.973 & Reliable \\
\hline
\end{tabular}

Source: WarpPLS 5.0 outputs, data processed (2021)

Table 10 shows the results of Cronbach's alpha testing where the latent variable value is $\geq 0.70$, which indicates that the data is reliable, so there are no problems in measuring the internal consistency in the model. The results of the Cronbach's Alpha test can be seen in table 10 below:

TABLE 10

CRONBACH'S ALPHA TEST

\begin{tabular}{lcl}
\hline Variabel & Cronbach's Alpha & Results \\
\hline Herding & 0.919 & Reliable \\
Overconfidence & 0.910 & Reliable \\
Investment Decision & 0.962 & Reliable \\
\hline
\end{tabular}

Source: WarpPLS 5.0 outputs, data processed (2021)

1) Structural Model Testing (Inner Model): Inner model testing is a concept and theory-based model development in order to analyze the relationship between exogenous and endogenous variables. The stages of testing the Inner model are as follows: The R-Square value is a goodness of the fit model test. It is found that the R-Square value of the investment decisions variable is 0.728 or $72.8 \%$. It can be explained by the herding and overconfidence variable in the research and the remaining $27.2 \%$ is explained by other variables.

Predictive Relevance (Q2) is a structural model that measures how well the observed value is generated by the model and also its parameter estimates. Predictive Relevance (Q2) is greater than 0. The outputs of Wrap-PLS show that the predictiverelevance value is 0.764 or $76.4 \%$ greater than 0 . So the exogenous latent variable of $76.4 \%$ is considered good or appropriate as an explanatory variable capable of predicting its endogenous latent variable.

2) Goodness of Fit Model (GoF): The GoF index is a single measure used to validate the combined performance of the measurement model (outer model) and structural model (inner model). The GoF value ranges from 0-1 with the following interpretations:

$$
\begin{aligned}
& G o F=\sqrt{A V E \times R^{2}} \\
& G o F=\sqrt{0.766 \times 0.728^{2}}
\end{aligned}
$$




$$
\begin{aligned}
& G o F=\sqrt{0.676 \times 0.530}=\sqrt{0.358} \\
& G o F=0.598
\end{aligned}
$$

The results of the calculation of Goodness of Fit $(\mathrm{GoF})$ for $\mathrm{R}^{2}$ is 0.598 or $59.8 \%$, meaning that there are $59.8 \%$ variations in the investment decision variables that can be explained by the variables used in this study. The next stage of the fit model in the WarpPLS 5.0 program can be seen from the general results to assess based on the fit indices model and the P-values display the results of ten fit indicators.

From the results of general SEM output on table 11, it can be explained that the Average path coefficient (APC) has an index of 0.614 with a p-value of $<0.001$. ARS has an index of 0.728 with a p-value of $<0.001$, while AARS has an index of 0.713 with a p-value $<0.001$ based on the above criteria, both APC, ARS and AARS. has met the criteria. For the AVIF value that must be $\leq 5$ has been fulfilled where the AVIF value is 2.302 and AFAVIF has also met the criteria $\leq 5$ based on data above the AFAVIF value is 2.514 . The GoF value is $0.637 \geq 0.36$ so that it meets the criteria and is classified as large. Then for SPR and RSCR meet the criteria because $\geq 0.7$ and for SSR values with a value of $0.937 \geq 0.7$ and NLBCDR with a value of $0.890 \geq$ 0.7 also meet the criteria. Thus the inner model can be accepted because it meets all the specified criteria. Following are the results of the General SEM Output presented in tabular form, namely:

TABLE 11.

\begin{tabular}{|c|c|c|c|c|}
\hline & Index & P-Value & $\begin{array}{l}\text { Criteria } \\
\text { (Ghozali, 2014) }\end{array}$ & Result \\
\hline APC & 0.614 & $<0.001$ & P-value $\leq 0.05$ & Be accepted \\
\hline ARS & 0.728 & $<0.001$ & $\mathrm{P}$-value $\leq 0.05$ & Be accepted \\
\hline AARS & 0.713 & $<0.001$ & P-value $\leq 0.05$ & Be accepted \\
\hline AVIF & 2.302 & & $\leq 5$, ideal $\leq 3.3$ & Be accepted \\
\hline AFVIF & 2.514 & & $\leq 5$, ideal $\leq 3.3$ & Be accepted \\
\hline GoF & 0.637 & & $\begin{array}{l}\geq 0.1 \text { Small }, \geq 0.25 \\
\text { Medium, } \geq 0.36 \text { Large }\end{array}$ & Be accepted (Large) \\
\hline SPR & 1.000 & & $\geq 0.7$, ideal 1 & Be accepted \\
\hline RSCR & 1.000 & & $\geq 0.7$, ideal 1 & Be accepted \\
\hline SSR & 0.937 & & $\geq 0.7$ & Be accepted \\
\hline NLBCDR & 0.890 & & $\geq 0.7$ & Be accepted \\
\hline
\end{tabular}

OUTPUT GENERAL SEM

Source: WarpPLS 5.0 outputs, data processed (2021)

\section{Hypothesis Testing Results}

Hypothesis testing is also intended to prove the truth of the research allegations or hypotheses. The results of the correlation between constructs were measured by looking at the path coeficients and their level of significance which were then compared with the research hypothesis. In Fig. 2. It can be seen that the herding variable (x1) has 6 indicators, the overconfidence variable (x2) has 6 indicators and the investment decision (Y) has 8 indicators. The image of the research model and the results obtained from the data processing output are as follows:

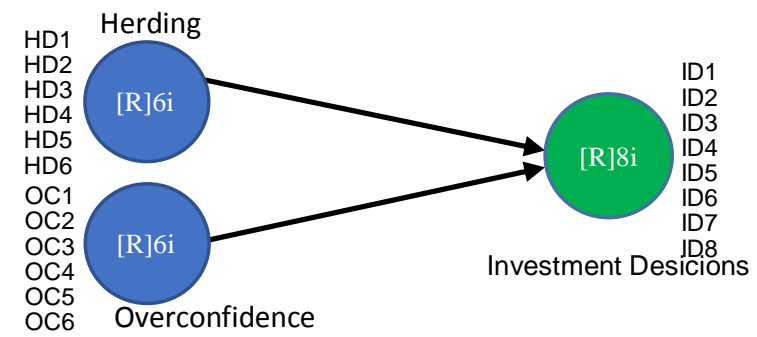

Fig. 2. Research Model with Indicators

Source: Output WarpPLS 5.0 (2021) 


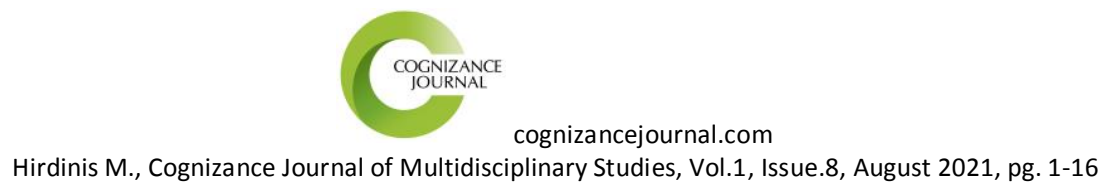

ISSN: 0976-7797

Furthermore, in Fig. 3, it can be seen that the herding variable has a significant effect on investment decisions with a pvalue $\leq 0.001$. This can be seen from the positive beta coefficient of 0.55 , this figure shows that there is an increase in the assessment of herding behavior, so investment decisions will also increase. While overconfidence has a positive and significant effect on investment decisions with a $p$-value $\leq 0.001$ and a positive beta coefficient of 0.40 . This figure shows that there is an increase in the assessment of overconfidence behavior which causes investment decisions to increase. These results can be seen in the Fig. 3. Research Model:

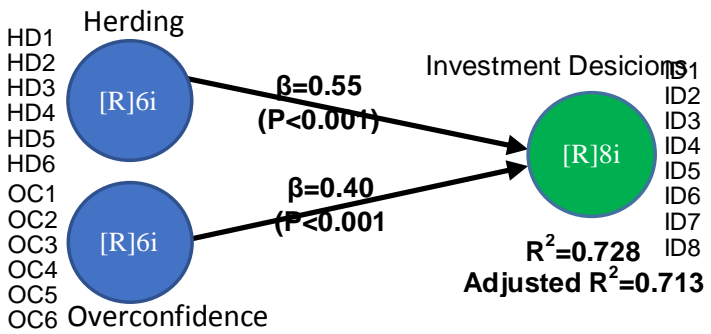

Fig. 3. Research Model

Source: Output WarpPLS 5.0 (2021)

The results of the indirect and total effects can be seen in Table 12, as follows:

Based on table 12, the Indirect and Total Effects output for hypothesis testing can be described as follows:

Hypothesis Test 1: Herding has a significant effect on investment decisions seen at p-values <0.001, so that Ha is accepted. Herding has a positive and significant effect on investment decisions. This effect can be observed through the path coefficient value which is positive, which is 0.548 . This shows that herding behavior is increasing and investment decisions by investors in the Jakarta area have also increased and vice versa. Every time there is a decline in herding behavior, investment decisions by investors in the Jakarta area will also decline.

Hypothesis Test 2: Overconfidence has a significant effect on investment decisions which can be seen from p-values $<0.001$, so that $\mathrm{Ha}$ is accepted. Overconfidence has a positive and significant effect on investment decisions where the path coefficient is positive, amounting to 0.401. This shows that if the overconfidence behavior of investors increases, then investment decisions by investors in the Jakarta area will increase and vice versa. Every time there is a decrease in overconfidence, investment decisions by investors in the Jakarta area will also decline.

TABLE 12,

INDIRECT AND TOTAL EFFECTS TEST RESULTS

\begin{tabular}{llccc}
\hline Criteria & Variable & Herding & Overconfidence & Investment Decisions \\
\hline Path coefficients & $\begin{array}{l}\text { Herding } \\
\text { Overconfidence } \\
\text { Investment Decisions }\end{array}$ & 0,548 & 0,401 & Be accepted \\
\hline p-values & $\begin{array}{l}\text { Herding } \\
\text { Overconfidence } \\
\text { Investment Decisions }\end{array}$ & $<0,001$ & $<0,001$ & Be accepted \\
\hline Effect sizes for path & $\begin{array}{l}\text { Herding } \\
\text { Overconfidence } \\
\text { Investment Decisions }\end{array}$ & 0,463 & 0,285 & Be accepted \\
\hline
\end{tabular}

Source: Output WarpPLS 5.0 (2021)

\section{E. Discussion}

Based on the results of the analysis of data processing using WrapPLS 5.0, the researcher will then discuss the analysis that has been carried out. This research was conducted to determine the effect of herding and overconfidence bias on investment decisions. To determine the effect, hypothesis testing is carried out so that it can be seen the effect of one variable on other variables.

The effect of herding on investment decisions: From the analysis, it is known that herding has a positive and significant effect on investment decisions. This means that the increasing herding behavior can encourage investment decisions by investors in the Jakarta area during the Covid-19 pandemic. This research is consistent with the research of Hadrian \& Adiputra 


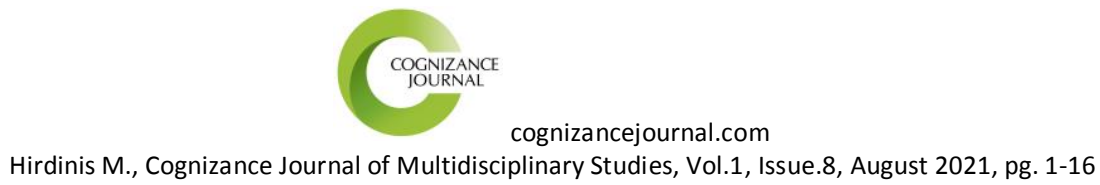

ISSN: 0976-7797

(2020), there is influences of herding effect on investment decision in the covid-19 pandemic period. The results of this study are supported by respondents' answers to statements with the highest mean values, namely: "Prefer to make investment decisions if there are many investor enthusiasms from the start." So during the Covid-19 pandemic, investors in the Jakarta area have a tendency to make investment-decisions following the many enthusiastic investors from the start of trading. The results of this study are also in accordance with several studies conducted by Qasim et al. (2018), Metawa et al. (2019), and Vo and Phan's (2016), it is stated that herding has a significant effect on investment decisions.

An investment-decision is a decision to buy, sell, or maintain share ownership, (Puspitaningtyas 2012). Investment decision-making does not always behave consistently according to the assumptions of the perception and understanding of the information received (Christanti and Mahastanti. 2011 and Peteros and Maleyeff. 2013). The results of this study are also in accordance with the findings of Chiang et al. (2013), which estimate that herding behavior across the Pacific equity markets is positively correlated, meaning that there are similarities in herding behavior in the region. Such as the research results of Madaan \& Singh's (2019) where herding bias has a significant positive impact on investment decisions. But it is not in accordance with the research of Trenca et.al. (2015) and Shah, Ahmad, and Mahmood (2018) stated that herding is not significant for investment decisions on individual investors. So herding behavior can be used by an investor to make investment decisions, but following other people needs a complete strategy and information so that the decisions made can give the best results.

The effect of overconfidence bias on investment decisions: Walters et al. (2019) stated that overconfidence bias often directed by the neglect of unknowns. From the analysis, it is known that overconfidence has a positive and significant effect on investment decisions. This means that increasing investor overconfidence can encourage investment decisions by investors in the Jakarta area. This is in accordance with the research conducted by Kumar \& Goyal (2015) which states that significant overconfidence in decision-making in household equity bias in developing countries. Research with the same results was also conducted by Metawa et al. (2019) and Madaan \& Singh (2019) states that overconfidence has a significant effect on investment decisions. Apart from these psychological factors, investment decisions are also influenced by several aspects such as: age, gender, education level, and income level. The effect of overconfidence on investment decisions during the Covid-19 pandemic is supported by the research statement with the highest score, namely believe in the decisions taken. So investors in the Jakarta area are overconfident about their investment decisions during the Covid-19 pandemic.

But the results of Shah, Ahmad, and Mahmood (2018) stated that had a markedly negative impact on investment decisions made by individual investors. Likewise, research according to Gozalie \& Anastasia (2015) states that overconfidence does not have a significant effect on investment decisions. So overconfidence for investors is needed to be able to achieve optimal results, even though overshadowed by the risk of loss.

\section{CONCLUSIONS AND SUGGESTIONS}

1). Conclusion: Based on the analysis and discussion of: Can herding and overconfidence encourage investment decisions by investors in the Jakarta area? Then the following conclusions can be drawn: Herding has a positive and significant effect on investment decisions by investors in the Jakarta area during the Covid-19 pandemic. This means that the increase in investor herding behavior can encourage investment decisions by investors in the Jakarta area. Overconfidence has a positive and significant effect on investment decisions by investors in the Jakarta area during the Covid-19 pandemic. This means that the increasing overconfidence of investors can encourage investment decisions by investors in the Jakarta area. So herding behavior and overconfidence can drive investment decisions by investors in the Jakarta area during the Covid-19 pandemic.

2). Suggestions: Based on the conclusions from the results of this study, several suggestions can be obtained as follows: This research is about how herding and overconfidence can drive investment decisions of investors in the Jakarta area. It is expected that future research can examine more complex variables in accordance with capital market developments and decision-making behavior by investors. This research is expected to be a consideration for investors in investing, especially from this study in accordance with indicators that have a low mean, namely: Investment decisions depend on other people's investment decisions, with the statement: Investing by imitating other people's decisions. The next low indicator is profit, with the statement: Investment decisions are chosen as long as profit without thinking carefully. This means that an investor must be able to modify the investment decisions made by other investors. To get profit, investors must understand that the decisions made are profitable or not. 


\section{REFERENCES}

[1] Pranita E. \& Nursastri S.A., Diumumkan Awal Maret, Ahli: Virus Corona Masuk Indonesia dari Januari Kompas.com,https://www.kompas.com/sains/read/2020/05/11/130600623/diumumkan-awal-maret-ahli--virus-coronamasuk-indonesia-dari-januari, 11/05/2020, accessed 20 December 2020.

[2] Azis A., What's wrong with Telkom? Investor Daily, https://investor.id/ market-and-corporate/ada-apa-dengan-telkom, accessed 25 November 2020.

[3] Suryanto dan Handoyo, Negative economic growth in the second quarter of 2020, due to low household consumption, Kontan.co.id, accessed October 5, 2020.

[4] Fauziana, L., Mulyaningsih A., Anggraeni E., Sadi Chaola Y. M, Rofida U. The Relation of Capital Investment to Indonesia's GDP. Economics Development Analysis Journal,3(2), 372-380, 2014, https://doi.org/10.15294/ edaj.v3i2.3845

[5] Muchayatin \& Dita S. (2018). Analysis of Investment Decisions in Increasing Company Value PT. Radiant Artha Raharja Sejahtera Semarang. Fiber Acitya - Journal of Untag Semarang, 7 (3), 39-49, 2018, ISSN: 2302-2752.

[6] BKPM, Investment Realization in Quarter III of 2020 Increases, The Investment Coordinating Board of the Republic of Indonesia, 2020.

[7] Press Release KSEI, 2020,

[8] Statman, M., Fisher, K. L., \& Anginer, D, Affect in a Behavioral Asset-Pricing Model. Financial Analysts Journal, 64(2), 20-29, 2008. https://doi.org/ 10.2469/faj.v64.n2.8.

[9] Antony, A., \& Joseph, A. I., Influence of Behavioural Factors Affecting Investment Decision-An AHP Analysis. Metamorphosis: A Journal of Management Research, 16(2), 107-114, 2017, doi: 10.1177/0972622517738833.

[10] Qasim, M., Hussain, R.Y., Mehboob, I., \& Arshad, M. Impact of herding behavior and overconfidence bias on investors' decision-making in Pakistan. University of Education, Lahore (Jauharabad Campus), Pakistan, 2018.

[11] Nengzih. Determinant of Corporate Governance, Audit Quality and Financing Decision. Research Journal of Finance and Accounting, 8(2017), 113-120.

[12] Trenca, I., Pece, A.M., \& Mihut, I.S. Herd behaviour of institutional and individual investors in The Context Ofeconomic Governance: Evidence from Romanian Stock Market. Babeş-Bolyai University, Faculty of Economics and Business Administration, Cluj-Napoca, Romania, 2015.

[13] Filip A., Pochea M., Pece A., The Herding Behaviour of Investors in the CEE Stocks Markets, Procedia Economics and Finance, 32 (2015), 307-315, ISSN 2212-5671, https://doi.org/10.1016/S2212-5671(15)01397-0.

[14] Tiniç, M., Iqbal, M. S., and Mahmud, S. F. Information cascades, shortselling constraints, and herding in equity markets. Borsa Istanbul Rev. 20, 347-357. 2020. doi: 10.1016/j.bir.2020.05.007

[15] Qin, J. To trade or not to trade: A model of regret and investment. Working Paper, APEA, Seattle, 2012.

[16] Vo, X.V. \& Phan, D.B.A. Herd Behavior in Emerging Equity Markets: Evidence from Vietnam. Asian Journal of Law and Economics, Volume 7, Issue 3, Pages 369-383, 2016, eISSN 2154-4611, ISSN 2194-6086, DOI: https://doi.org/10.1515/ ajle-2016-0020.

[17] Metawa, N., Hassan, M.K., Metawa, S. and Safa, M.F. "Impact of behavioral factors on investors' financial decisions: case of the Egyptian stock market", International Journal of Islamic and Middle Eastern Finance and Management, Vol. 12 No. 1, pp. 30-55, 2019, https://doi.org/10.1108/IMEFM-12-2017-0333.

[18] Bakar S. and Amelia Ng Chui Yi, The Impact of Psychological Factors on Investors' Decision Making in Malaysian Stock Market: A Case of Klang Valley and Pahang, Procedia Economics and Finance 35 (2016) 319 - 328.

[19] Ady, S.U. Management Psychology in Stock Investment. Yogyakarta: Andi Offset, 2015.

[20] Bouteska A. \& Regaieg B., "Overconfidence Bias, Over/ Under-reaction of Financial Analysts on the Tunisian Stock Market, and Their Impacts on the Earnings Forecasts," International Journal of Economics and Financial Issues, Econjournals, vol. 7(2), pages 208-214, 2017.

[21] Shah, S.Z.A., Ahmad, M. and Mahmood, F. "Heuristic biases in investment decision-making and perceived market efficiency: A survey at the Pakistan stock exchange", Qualitative Research in Financial Markets, Vol. 10 No. 1, pp. 85110. 2018, https://doi.org/10.1108/QRFM-04-2017-0033.

[22] Grežo, M. "Overconfidence and financial decision-making: a meta-analysis", Review of Behavioral Finance, Vol. 13 No. 3, pp. 276-296. 2021. https://doi.org/10.1108/RBF-01-2020-0020.

[23] Herlina, Hadianto, B.M., Winarto, J., and Suwarno, N. A. N., The Herding and Overconfidence Effect on the Decision of Individuals to Invest Stocks. Journal of Economics and Business, Vol.3, No.4, 1387-1397, 2020. 


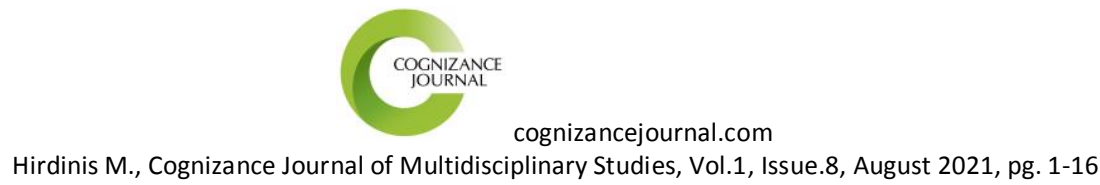

ISSN: 0976-7797

[24] Gozalie, S., \& Anastasia, N., The Influence of Heuristics and Herding Behavior on Residential Property Investment Decision Making. Finesta Journal, Vol. 3(2): 28-32. 2015.

[25] Bodie Z., Kane A., Marcus A. J., Investments, Eleventh Edition, Singapore, McGraw-Hill Education, 2018.

[26] Zulfikar. Introduction to Capital Markets with a Statistical Approach, Yogyakarta, Publisher Deepublish, 2016.

[27] Azis, M., Mintarti, S., \& Nadir, M. Fundamental Investment Management, Technical, Investor Behavior and Stock Return. DEEPUBLISH (CV BUDI UTAMA Publishing Group). Yogyakarta, 2015.

[28] Tandelilin, E. (2017). Capital markets: portfolio \& investment management, Canisius Publishers. Yogyakarta.

[29] Pratiwi, I., \& Prijati. The Influence of Demographic Factors on Investment Types and Behavior of Surabaya Capital Market Investors. Journal of Management Science and Research, 4(2), 1-15. 2015.

[30] Puspitaningtyas, Z. Value relevance of accounting information and its benefits to investors. Equity: Journal of Economics and Finance, 16(2), 164-183, 2012.

[31] Chrisanti, N. \& Milandari. Factors Investors Consider in Making Investments, Journal of Theoretical and Applied Management, Year 4, No. 3: 37 - 52, 2011.

[32] Peteros, R. dan Maleyeff, J. Application of Behavioral Finance Concept to Investment Decision Making: Suggestion for Improving Investment Education Courses. International Journal of Management. Vol. 30, No. 1: 249 - $261,2013$.

[33] Pasewark W. R. dan Riley M. E, It's a Matter of Principle: The Role of Personal Values in Investment Decisions, Journal of Business Ethics, 2010, vol. 93, issue 2, 237-253.

[34] Wulandari, D. A., dan Rr. Iramani. Study of Experienced Regret, Risk Tolerance, Overconfidance and Risk Perception in Economics Lecturer Investment Decision Making, Journal of Business and Banking, 4(1), 55 - 66, 2014.

[35] Sukirno, S. Introduction to Macroeconomic Theory, Third Edition. Jakarta: PT Raja Grafindo Persada, 2015.

[36] Komalasari, P.T. Information Asymmetry and Herding Behavior, Indonesian Journal of Accounting and Finance, June, 2016, Vol. 13, No. 1, pp. $70-85$.

[37] Chaffai, M., and Medhioub, I. Herding behaviour in Islamic GCC stock market? a daily analysis. Int. J. Islamic Middle Eastern Finance Manag. 11, 182-193. 2018. doi: 10.1108/imefm-08-2017-0220

[38] Kremer, S. \& Nautz, D., "Causes and Consequences of Short-term Institutional Herding," Journal of Banking \& Finance, Elsevier, vol. 37(5), 2013, pages 1676-1686.

[39] Rahayu, S., Rohman, A., \& Harto, P, Herding Behavior Model in Investment Decision on Emerging Markets: Experimental in Indonesia. The Journal of Asian Finance, Economics and Business, 8(1), 53-59., https://doi.org/10.13106/JAFEB.2021.

[40] Galariotis, E. C., Rong, W., \& Spyrou, S. I., Herding on Fundamental Information: A Comparative Study, Journal of Banking \& Finance, 50, 589-598, 2015, https://www.sciencedirect.com/science/article/abs/pii/S0378426614000971, https://doi.org/ 10.1016/j.jbankfin.2014.03.014.

[41] Chiang T., Tan L., Li J., \& Nelling E., "Dynamic Herding Behavior in Pacific-Basin Markets: Evidence and Implications," Multinational Finance Journal, vol. 17(3-4), pages 165-200, 2013.

[42] Chen, A. \& Pelger, M., How Relative Compensation Can Lead to Herding Behavior (November 21, 2013). Available at SSRN: https://ssrn.com/abstract=2217715 or http://dx.doi.org/10.2139/ssrn.2217715.

[43] Pompian, M.M., CFA. (May/June 2017). Risk Tolerance and Behavioral Finance. Investments \& Wealth Monitor 11-14. Retrieved Oct. \& Nov., 2017.

[44] Pompian, M.M., Behavioral Finance and Investor Types: Managing Behavior to Make Better Investment Decisions, Hoboken, New Jersey, John Wiley \& Sons, 2012.

[45] Supramono \& Wandita, M. Confirmation Bias, Self-Attribution Bias, and Overconfidence in stock transactions, Journal of Finance and Banking,. 21 (1), 25 - 36, 2017.

[46] Mushinada, V. N. C., \& Veluri, V. S. S. Investors overconfidence behaviour at Bombay Stock Exchange. International Journal of Managerial Finance, 14(5), 613-632. 2018, https://doi.org/10.1108/IJMF-05-2017-0093.

[47] Phan, T. C., Rieger, M. O., \& Wang, M. What Leads to Overtrading and Under-diversification? Survey Evidence from Retail Investors in an Emerging Market. Journal of Behavioral and Experimental Finance, 19(2018), 39-55. https://doi.org/10.1016/j.jbef.2018.04.001.

[48] Sugiyono. Research Methods: Quantitative, Qualitative, and R\&D, Bandung, Alfabeta. 2016.

[49] Rosenberg B. D. \& Navarro M. A., The SAGE Encyclopedia of Educational Research, Measurement, and Evaluation: "Semantic Differential Scaling", Thousand-Oaks, SAGE Publications, Inc, 2018, http://dx.doi.org/10.4135/ 9781506326139.n624.

[50] Kumar, S. \& Goyal, N. Behavioural biases in investment decision making - a systematic literature review. Qualitative Research in Financial Markets, 7 (1), 88-108, 2015, DOI: 10.1108/QRFM-07-2014-0022. 
[51] Fityani I. \& E. D. Arfianto, " Investor Herding Behavior Analysis with Multinomial Logit Regression on the IDX (Case Study on LQ-45 Stocks for the 2009-2014 Period)," Diponegoro Journal of Management, 4 (3), 698-711, 2015

[52] Subash, R. Role of Behavioral Finance in Portofolio Investment Decisions: Evidence From India. Charles University in Prague, 2012

[53] Setiawan, Y.C., Atahau, A.D.R., \& Robiyanto. Cognitive Dissonance Bias, Overconfidence Bias and Herding Bias in Making Stock Investment Decisions, AFRe: Accounting and Financial Review, 1 (1), 17-25, 2018

[54] Hair, J. F., Jr., Hult, G. T. M., Ringle, C., \& Sarstedt, M, A primer on partial least squares structural equation modeling (PLS-SEM) (2nd ed.). Thousand Oaks: SAGE Publications, 2016.

[55] Ghozali, I, Structural Equation Modeling, Alternative Method with Partial Least Square (PLS). Edition 4. Semarang: Diponegoro University Publishing Agency, 2016.

[56] Madaan G. \& Singh S. An Analysis of Behavioral Biases in Investment Decision-Making, International Journal of Financial Research, Vol. 10, No. 4; 2019, pages.55-67.

[57] Hadrian \& Adiputra I. G., The Influence of Overconfidence, Herding Effect, Self-Monitoring on Investment Decisions during the Covid-19 Pandemic, Journal of Managerial And Entrepreneurship, II (3), 595-602, 2020.

[58] Ahmad, M. and Shah, S.Z.A. (2020), "Overconfidence heuristic-driven bias in investment decision-making and performance: mediating effects of risk perception and moderating effects of financial literacy", Journal of Economic and Administrative Sciences, Vol. ahead-of-print No. ahead-of-print. https://doi.org/10.1108/JEAS-07-2020-0116.

[59] Walters, D. J., Fernbach, P. M., Fox, C. R., \& Sloman, S. A. Known Unknowns: A Critical Determinant of Confidence and Calibration. Management Science. 2016, https://doi.org/10.1287/mnsc.2016.2580.

[60] Shah, S.Z.A., Ahmad, M. and Mahmood, F., "Heuristic biases in investment decision-making and perceived market efficiency: A survey at the Pakistan stock exchange", Qualitative Research in Financial Markets, Vol. 10 No. 1, pp. 85110. 2018. https://doi.org/10.1108/QRFM-04-2017-0033

[61] Rahim, A., Shah, M. H., Jan, S.U. and Aamir, A., Post COVID-19 Influence of Overconfidence Bias on Investment Decisions of Pakistani Stock Investors (October 14, 2020). International Journal of Management, 11(9), 2020, pp. 973981. 